\title{
Entrepreneurship as a means to Employment First: How can it work?
}

\author{
Michelle Ouimette ${ }^{\mathrm{a}}$ and Linda H. Rammler ${ }^{\mathrm{b}, *}$ \\ ${ }^{a}$ Managing Director of Roses for Autism and Discover Learn Work, Services of Ability Beyond, Inc., \\ Bethel, CT, USA \\ ${ }^{\mathrm{b}}$ University of Connecticut Center for Excellence in Developmental Disabilities, Farmington, CT, USA
}

Revised/Accepted November 2016

\begin{abstract}
.
BACKGROUND: Customized employment opportunities are successful ways to employ individuals with disabilities because there is a specific match between the needs of an employer and the strengths and preferences of an individual with a disability. OBJECTIVE: This article describes one non-profit's success in meeting the goals of Employment First initiatives for individuals with significant disabilities through entrepreneurship as a means of customized employment.

CONCLUSION: Successful opportunities and innovations include the "right kind" of social enterprise, entrepreneurship through self-employment and micro-enterprises, and other entrepreneurial models. Strategies for resolving the real and perceived conflicts between entrepreneurial and non-profit business models, as well as lessons learned during our own transformation, are discussed for other organizations wishing to reorganize their missions and operations from traditional (pre)vocational providers to ones that truly support integrated, competitive employment for all.
\end{abstract}

Keywords: Employment, customized employment, self-employment, entrepreneurship, Employment First, autism, behavioral, mental health, intellectual and developmental disabilities, social enterprise

\section{Introduction}

Some 50 years ago, "entrepreneurship" was almost a dreaded word among many human services personnel. There seemed to be a divide between those who cared more about comfortable lifestyles/making money and those who cared more about the environment, personal decision-making, and the plight of those we considered less fortunate than ourselves (Hoyt, 2014). Unfortunately, some of the systemic actions taken to address environmental issues (Konisky, 2015), personal decision-making (Twenge, 2014), and the plight of those we considered less fortunate than ourselves led to the institu-

\footnotetext{
*Address for correspondence: Linda H. Rammler, University of Connecticut Center for Excellence in Developmental Disabilities, 263 Farmington Ave., MC6222, Farmington, CT 06030, USA. Tel.: +1 860679 1585; Fax: +1 860679 1571; E-mail: 1rammler@uchc.edu.
}

tionalized poverty of too many (Rector \& Lauber, 1995; Shipler, 2008), including those with disabilities (Hughes, 2013).

The effort to "employ" marginalized people with disabilities were non-profit business models built upon how best "to take care of" them by providing a continuum of services (including day habilitation programs, sheltered workshops, and social clubs) under the mistaken belief that people could graduate from a more restrictive level to a less restrictive one and, maybe by the time they were in their $60 \mathrm{~s}$, achieve unsupported but integrated competitive employment. In doing so, social policy resulted in a financially unsustainable infrastructure of human services which continues the cycle of care taking, poverty, and exclusion (Alan Bergman, personal communication, November 14, 2016; Eggers \& Macmillan, 2013).

As our national and local economies, as well as values-based developments in human services, 
demanded a look toward more equitable economic participation for all in the decades since, we found how difficult it can be, in our turbulent economic environment, for many marginalized people to get jobs of any kind - never mind ones that were satisfying to them and lead toward economic self-sufficiency (Agranoff, 2013; Block, Kasnitz, Nishida, \& Pollard, 2015; Butterworth, Migliore, Sulewski, \& Zalewska, 2014; Iceland, 2013).

The Association of People Supporting Employment First (APSE) adopted a strong statement embracing a growing national movement that recognized and responded to the failure of the "continuum of (pre)vocational services leading to employment" system. The statement reads "Employment in the general workforce is the first and preferred outcome in the provision of publicly funded services for all working age citizens with disabilities, regardless of level of disability" (APSE, 2010). Others have followed suit and Employment First initiatives at the local, state, and national levels systematically are working to reform the forced dependency on human services staff, chronic boredom, social isolation, and institutionalized poverty that were the outcomes for too many people with disabilities as a result of these earlier social policies (Billstedt, Gillberg, \& Gillberg, 2005). Economically and in terms of broader social justice concerns, this social policy change makes enormous sense as well (Maier, Meyer, \& Steinbereithner, 2016; Millman, 2000) and has recently been codified by the federal Workforce Innovation and Opportunity Act (United States Department of Labor, 2014).

\section{Entrepreneurship as a means of customized employment}

According to the United States Department of Labor (USDoL), "Customized Employment" (CE) is a means toward employment first by providing a flexible process involving a personalized relationship between an employee and employer resulting in a "win-win" for both. Customized employment opportunities by definition are successful because there is a specific match between the employer's needs and the strengths, preferences, interests, talents, and what works/doesn't work for the individual with a disability that the employer can, as part of his/her day-to-day business practices or with minimal reasonable accommodations, provide. The employer is not being charitable; s/he gains an employee who is capable, dependable and will ultimately benefit business productivity and profitability, and the employee gains a paycheck with compensation at or above minimum wage, feels a sense of purpose, and becomes part of a social community with nondisabled coworkers, customers, etc. From a job development perspective, customized employment relies upon relationships with businesses that are cultivated to result in task reassignment, job carves, or job sharing (USDoL, n.d.)

Through customized employment, and despite ongoing challenges, an increasing number of people with disabilities have achieved integrated competitive employment including those with autism and behavioral/mental health challenges (Burgess \& Cimera, 2014; Hall, Butterworth, Winsor, Gilmore, \& Metzel, 2007; Hendricks, 2010; McDonough \& Revell, 2010; Rogers, Lavin, Ran, Gantenbein, \& Sharpe, 2008; Wehman et al., 2014; Wehman et al., 2016). Nonetheless, some people with disabilities still remain un- or underemployed because of the lack of job openings for which they are well-suited. For these individuals, entrepreneurship can offer a viable solution.

Entrepreneurship among people without disabilities has taken many forms (for example, mega-companies, chain stores, "mom and pop" storefronts, self-employment, working as independent contractors, and home-based industries) generally intended to provide services or produce goods in order to contribute to the overall economy as well as economic self-sufficiency on the part of the entrepreneurs (Hamilton, 2012; Griffin, Hammis, Geary, \& Sullivan, 2008). People with disabilities have the same right to self-determine which employment options are most satisfying to them (Doyle, 2012), including participation in entrepreneurial opportunities.

Entrepreneurship in a non-profit organization (NPO) context seems paradoxical because the fundamental design of NPOs is to emphasize social missions. Profits derived from the sale of goods and services are not distributed to organizational stakeholders but turned back into "the cause." Some question whether it is valuable for NPOs to innovate, take risks, or engage in a process of "creative destruction" as part of the entrepreneurial process (Kaplan \& Grossman, 2010). A strongly held assumption is that, to do so, would dedicate valuable and limited resources to entrepreneurial initiatives, compromising service provision to those "in need." Another concern is about "mission drift" and any focus on sales and profit creation - even in 
support of "those in need" - is met with disdain by some stakeholders (Greer \& Horst, 2014). However, putting entrepreneurship in the context of customized employment, rather than solely as a challenge for NPOs trying to stay alive in today's economy, leads us to examine two types of entrepreneurship the varied nuances of which, for our purposes, we will simplify into a dichotomy of "Opportunity Driven Entrepreneurship" versus "Necessity Driven Entrepreneurship" (Komisar, 2007; Williams, 2007, 2009). The former involves recognizing opportunities in the market and assembling resources (assets, knowledge, and relationships) to capitalize on those opportunities - a stretch for some people with disabilities and NPOs. The latter involves pursuing entrepreneurial activities as a means of survival because there are few or no other alternatives. As such, necessity-driven entrepreneurship can apply to both individuals with disabilities as well as NPOs (Bryson, Gibbons, \& Shaye, 2001; Sabeti, 2011; Verheul, Thurik, Hessels, \& van der Zwan, 2010).

Necessity-driven entrepreneurship in a variety of capacities furthers Employment First goals. There is a place for a) "the right kind" of social enterprise, b) self-employment through microbusinesses, and c) other entrepreneurial opportunities. We have developed and sustained the first two models, and are exploring the third, focusing specifically on individuals with labels of autism, mental health/behavioral challenges, and significant intellectual and developmental disabilities, some of whom others have said could never work. Through some trial and error, we now know NPOs involved in employment must have a solid understanding of functional business models to meet the varied needs of these individuals - as well as the demands of their varied funding streams - across the varied types of ventures which we will now discuss.

\section{The "right kind" of social enterprise}

Social entrepreneurship, resulting in a "social enterprise," represents the evolution of the private sector with the social and public sector. While the notion of social entrepreneurship is often romanticized ("do good/feel good") in mainstream media (Schectman, 2010), these hybrid business forms are particularly challenging because social missions and traditional business objectives, i.e. profitability, are associated with divergent goals, values, norms and identities (Aileen Boluk \& Mottiar, 2014). Attending to them simultaneously creates tensions, competing demands, and ethical dilemmas (Smith, Gonin, \& Besharov, 2013). To be successful, entrepreneurs must create viable business models based upon market principles (e.g., provision of goods or services that people are willing to pay for, ensure revenues are sufficient to cover business expenses, and plan for future growth while remaining relevant and competitive) in addition to benefitting the social mission. Yet rarely, we have found, is there sufficient time, energy, knowledge, and financial resources dedicated to properly researching and developing a sustainable business plan that will meet both financial and social objectives! As a result, we learned from our own experience in the early years of Roses for Autism, and by observing trailblazers like Ben \& Jerry's and Newman's Own, that the market won't pay a premium for goods (i.e. a $\$ 50$ brownie) just because it benefits a social cause. Unless your social enterprise can break even financially, the any well-intentioned blending of free enterprise with a true social conscience (Tomaino, 2011) was destined for failure.

The "right kind" of social enterprise is one that instead addresses the previous issues in providing integrated, competitive jobs while responding to both market and public policy needs with transformative and financially sustainable innovations. These ventures can be large or small as there is no size qualifier. Social enterprise, as a hybrid business model, can demonstrate Employment First to other businesses, policy-makers, and advocates for economic equity who see employees with and without disabilities prosper in productive work environments. Concerns about hiring people with disabilities are thereby dispelled. In addition, experiential learning is essential for many with disabilities and employment in social enterprises provides in vivo opportunities to acquire technical skills (e.g., in graphic design, emarketing, floral arrangement) as well as professional skills needed to be successful employees. Career interests and abilities can be matched with available jobs in dynamic businesses. For example, those who prefer travel and movement make deliveries whereas those with excellent attention to detail and a preference for sedentary work can process internet orders. The right kind of social enterprise is part of the labor market and, perhaps most importantly, such businesses are integral to the local community. NPO-run social enterprises also allow transition-aged students to discover various occupations and learn what they may wish to pursue as future employment goals. Today, the current "Roses for Autism" (RFA) 
model of Ability Beyond, Inc., is one successful example.

\section{Lessons learned about the "right kind" of social enterprise}

NPOs considering replication of the RFA model can benefit from what we have learned since RFAs inception. First, NPOs need to conduct a SWOT (strengths, weaknesses, opportunities, and threats) or similar analyses before making a commitment. It is dangerous to assume there will be a market because there "should be" for charitable purposes. Second, it is important to avoid "sun-setting" or already closed businesses. Instead, NPOs should explore successful franchises or well-established businesses with retiring owners looking for successors. Third, business plans based on vetted revenue models are essential before making an investment.

The leadership of an NPO-run social enterprise must be able to make balanced business decisions that honor the NPO's social mission while generating sufficient revenue to cover costs of operations. We learned not to hire trainees unless there is a legitimate business interest to do so in order to maintain a flow of "first job" opportunities for those who can and must move on to employment elsewhere. Further, time and resources must be devoted to marketing the business because the product/service is exceptional and meets the needs or desires of the customer.

Crises and failures nonetheless present opportunities to reassess, redesign, and move forward with new knowledge and assurances. Given that some estimates of failure rates for business start-ups are as high as 8 out of 10 start-ups within the first 18 months (Haltiwanger, Jarmin, \& Miranda, 2012; Wagner, 2013), we have changed our business model several times in order to avoid becoming one of those statistics.

\section{Entrepreneurship through self-employment and micro-enterprises}

Entrepreneurship through self-employment and microenterprises owned by individuals with disabilities is a subset of customized employment that is becoming more common (USDoL, n.d.). While incorporating a similar process of discovery, skill matching, individualization, and assembly of necessary supports, this form of entrepreneurship offers specific advantages by, e.g.:
- providing solutions to many employment barriers (e.g., lack of transportation, workplace discrimination, and the absence of available jobs in which the individual is skilled).

- accommodating needs of individuals with severe mental health/behavioral challenges or health conditions through flexible scheduling and leave for emergency treatment.

- providing a direct route to achieving the individual's self-determined career goals.

- providing a sense of achievement and satisfaction that might not otherwise come from working for or even with others.

- resulting in better economic outcomes for those who are self-employed than for those working for others (Revell, Smith, \& Inge, 2009).

In 2013, the federal Office of Disability Employment Policy (ODEP) issued a report, SelfEmployment for People with Disabilities, which concluded that self-employment should be among the national disability employment policy priorities. Specific recommendations were made to align policy across systems, promote cross-system collaboration and braiding of resources, and encourage public and private sector investment in businesses owned by people with disabilities (ODEP, 2013). Although, to date, few of the recommendations have been pursued, we have been honored to assist with the start-up of a handful of successful self-employment microenterprises such as "D.J. Stevie B" and "Vioude's Designs." More of these strengths- and interest-based pursuits are in the works.

Such "microenterprises" or "microbusinesses" are defined as small-scale simple businesses, usually owner-operated with less than 10 (if any) employees (Head, 2015). These entrepreneurial opportunities may not have a powerful impact on the overall economy (Muske, Woods, Swinney, \& Khoo, 2007) but are especially viable for individuals with disabilities who are a) not easily matched to customized employment involving working for and with others and/or b) passionate about, and skilled in, providing a particular good or service to the marketplace. Start-up costs are low and not contingent on borrowing money. In addition, those relying on established business models like a DJ service, jewelry design/consignment, and basic food sales require simple business plans easily based on well-established templates readily available, e.g., online. There is low overhead and thus less financial risk to the individual. 


\section{Lessons learned about microbusinesses}

Entrepreneurs with disabilities generally benefit from a basic knowledge of business practices if their self-employment is to be as independent as possible. In response to this need, we now offer a communitybased six-week summer course called Explorations in Entrepreneurship as well as provide individualized adult education about entrepreneurship. We learned from the lack of success of one entrepreneurial enthusiast how important it is for start-ups to embrace "the Hedgehog concept" (Collins, 2001), i.e., focusing on one product or service that is most important to the individual.

As with many employment situations for individuals with disabilities, the owner/operator of a microenterprise still may need ongoing support from volunteers (e.g., members of the local Small Business Association, SCORE [formerly the Service Corps of Retired Executives, currently SCORE, Counselors to America's Small Business], other Chamber of Commerce mentors) or family members. NPO staff, in addition to providing some on-going support, can be essential to establishing these other relationships and fading out. We learned that successful microenterprises benefit greatly from having a "micro-board of directors" for long-term support.

"Word-of-mouth" marketing only gets microentrepreneurs so far. Entrepreneurs rely upon their networks and the networks of their supporters to generate initial sales and support. Entrepreneurs with disabilities also may need assistance in developing a broader promotion strategy which may include the cost of "freebies" as requested, and to plan for a portion of business revenues to cover advertising and promotion expenses. The lack of immediate financial gratification and recognition as an entrepreneur can be difficult for some individuals to manage emotionally, particularly when they have a history of chronic unemployment or employment failure. Emotional support, then, is as critical as support for business operations.

\section{Other entrepreneurial models}

Larger enterprises involve investors of time, expertise, and cash which can pose grave challenges for individuals who may not have or are dependent on others for their community connections or who do not have credit ratings or collateral. When investors are found, there is an expectation of growth that may be challenging to support without "the right kind" of board of directors (Alsever, 2015). As such, family supported small businesses may offer a better option - one we are currently pursuing with a purveyor of home-made lemonade. Like the situation of Joe Steffy, sole proprietor of "Poppin' Joe's TM Gourmet Kettle Korn" launched just over 10 years ago at this writing, we are building the collaborative capacity of J's family and other community members to establish his family-supported small business. Mr. Steffy's family wished “... to provide Joe, a young adult with (Down Syndrome and Autism), the opportunity to operate and manage his own business. By doing so, Joe has developed an excellent work ethic and realizes the value of good, hard work." More importantly, Mr. Steffy provides a valued product to an ever-increasing geographical area and, with support for managing the business affairs of his company, has become economically self-sufficient (Source: http://poppinjoes.com/; personal communication, Ray Steffy, October 5, 2014). J and his family, with initial support from our NPO, are seeking the same.

We are exploring many more options, too. For families able to support their family member with disabilities in becoming owner/entrepreneurs, other considerations include buying into franchises or arranging for the individual to legally co-own a partnership or Limited Liability Corporation with a trusted individual. Inclusive collectives, particularly for artists, support another form of self-employment (The Autism Acceptance Project, 2013). When access to funding is needed, many entrepreneurs such as our friend, Nick Glomb, proprietor of Family \& Friends Roadside Cart, use GoFundMe.com (https://www.gofundme.com/ 25qgep7h) or other crowd-source platforms to generate their start-up cash. Disability.gov is a federal website with a variety of resources and advice articles specifically for entrepreneurs with disabilities. For learning nuts and bolts of business operations including where one may need ongoing mentoring or more intensive support - there also are American Job Centers.

\section{Conclusion}

In conclusion, we are finding that entrepreneurship is a viable means to Employment First for all whether through the "right kind" of social enterprise, a microbusiness, or family supported endeavor that 
involves community integration and, with the same perseverance other entrepreneurs have, a high potential for not just a competitive wage but one that can actually result in self-sufficiency. In other words, it CAN Work!

\section{Acknowledgments}

We would like to thank the staffs of the University of Connecticut Center for Excellence in Developmental Disabilities, Ability Beyond, Inc., and Roses for Autism, Inc., who support this project directly and indirectly as well as the Connecticut Council on Developmental Disabilities and YASBIZ, a Young Adult Service of the CT Department of Mental Health, which provided start-up funds for some of the entrepreneurs. Appreciation also goes out to the many members of our Greater New Haven and Greater Hartford business communities who lent expertise to these start-ups. We mostly would like to thank the entrepreneurs, themselves, for their vision, determination, and hard work.

\section{Conflict of interest}

The authors have no conflict of interest to report.

\section{References}

Agranoff, R. (2013). The transformation of public sector intellectual/developmental disabilities programming. Public Administration Review, 73, 127-138.

Aileen Boluk, K., \& Mottiar, Z. (2014). Motivations of social entrepreneurs: Blurring the social contribution and profits dichotomy. Social Enterprise Journal, 10(1), 53-68.

Alsever, J. (2015). Startups... inside giant companies. Fortune e-magazine. http://fortune.com/2015/04/26/startups-insidegiant-companies/

Association of People Supporting Employment First (2010). APSE Statement on Employment First (2010). Rockville, MD: Author. http://www.apse.org/wp-content/uploads/2014/ 04/APSE-Employment-First-Statement.pdf

Billstedt. E., Gillberg, C., \& Gillberg, C. (2005) Autism after adolescence: Population-based 13- to 22-year follow-up study of 120 individuals with autism diagnosed in childhood. Journal of Autism and Developmental Disorders, 35(3), 351-360.

Block, P., Kasnitz, D., Nishida, A., \& Pollard, N. (Eds.) (2015). Occupying Disability: Critical Approaches to Community, Justice, and Decolonizing Disability. Springer.

Bryson, J. M., Gibbons, M. J., \& Shaye, G. (2001). Enterprise schemes for nonprofit survival, growth, and effectiveness. Nonprofit Management and Leadership, 11, 271-288.
Burgess, S., \& Cimera, R. E. (2014). Employment outcomes of transition-aged adults with autism spectrum disorders: A state of the states report. American Journal on Intellectual and Developmental Disabilities, 119, 64-83.

Butterworth, J., Migliore, A., Sulewski, J. S., Zalewska, A. (2014). Trends in employment outcomes of young adults with intellectual and developmental disabilities 2004-2012. Boston, MA: University of Massachusetts Boston, Institute for Community Inclusion.

Collins, J. C. (2001). Good to great: Why some companies make the leap... and others don't. New York: HarperCollins Publishing Co.

Doyle, A. (2002). Self-employment, choice, and selfdetermination. Journal of Vocational Rehabilitation, 17, 115-124.

Eggers, W. D., \& Macmillan, P. (2013). The solution revolution: How business, government, and social enterprises are teaming up to solve society's toughest problems. Harvard Business Review Press.

Greer, P., \& Horst, C. (2014). Mission Drift: The unspoken crisis facing leaders, charities, and churches. Baker Books.

Griffin, C., Hammis, D., Geary, T., \& Sullivan, M. (2008). Customized employment: Where we are; where we're headed. Journal of Vocational Rehabilitation, 28, 135-139.

Hall, A. C., Butterworth, J., Winsor, J., Gilmore, D. S., \& Metzel, D. (2007). Pushing the employment agenda: Case study research of high performing states in integrated employment. Intellectual and Developmental Disabilities, 45(3), 182-198.

Haltiwanger, J., Jarmin, R., \& Miranda, J. (2012). Business Statistics Briefing 6: Where have all the young firms gone? Retrieved from https://www.census.gov/ces/pdf/BDS_ StatBrief6_Young_Firms.pdf

Hamilton, V. (2012), "Career Pathway and Cluster Skill Development: Promising Models from the United States", OECD Local Economic and Employment Development (LEED) Working Papers, 2012/14, OECD Publishing. http:// dx.doi.org/10.1787/5k94g1s6f7td-en

Head, B. (2015). The role of microbusinesses in the economy. Small Business Association Office of Advocacy. Washington, DC. https://www.sba.gov/sites/default/files/ Microbusinesses_in_the_Economy.pdf

Hendricks, D. (2010). Employment and adults with autism spectrum disorders: Challenges and strategies for success. Journal of Vocational Rehabilitation, 32, 125-134

Hoyt, D. P. (2014). The solution revolution: How business, government, and social enterprise are teaming up to solve society's toughest problems. Research-Technology Management, 57(5), 61.

Hughes, C. (2013). Poverty and disability: Addressing the challenge of inequality. Career Development and Transition for Exceptional Individuals, 36, 37-42.

Iceland, J. (2013). Poverty in America: A handbook. Berkeley: University of California Press.

Kaplan, R. S., \& Grossman, A. S. (2010). The emerging capital market for nonprofits. Harvard Business Review, 88(10), 110-118.

Komisar, R. (2007). Necessity-Driven Entrepreneurship. Presented at the Stanford Technology Ventures Program Endeavor's Entrepreneurs' Summit, Stanford, CA. https://www.youtube.com/watch?v=_2AUD6acjpc 
Konisky, D. M. (2015). Failed Promises: Evaluating the Federal Government's Response to Environmental Justice. Cambridge, MA: MIT Press.

Maier, F., Meyer, M., \& Steinbereithner, M. (2016). Nonprofit Organizations Becoming Business-Like A Systematic Review. Nonprofit and Voluntary Sector Quarterly, 45, 64-86.

McDonough, J. T., \& Revell, G. (2010). Accessing employment supports in the adult system for transitioning youth with autism spectrum disorders. Journal of Vocational Rehabilitation, 32, 89-100.

Millman, D. (2000). Way of the peaceful warrior: A book that changes lives. Tiburon, CA: HJ Kramer.

Muske, G., Woods, M., Swinney, J., \& Khoo, C. (2007). Small Businesses and the Community: Their Role and Importance within a State's Economy. Journal of Extension, 45(1). Retrieved from https://joe.org/joe/2007february/rb4.php

Office of Disability and Employment Policy (2016). Disability Statistics. Washington, DC: United States Department of Labor. Source. https://www.dol.gov/odep/

Rector, R., \& Lauber, W. F. (1995). America's failed \$5.4 trillion war on poverty. Washington, D.C.: Heritage Foundation.

Revell, G., Smith, F., \& Inge, K. (2009). An analysis of selfemployment outcomes within the federal/state Vocational Rehabilitation system. Journal of Vocational Rehabilitation, 31, 11-18. (p.15)

Rogers, C., Lavin, D., Ran, T., Gantenbein, T., \& Sharpe, M. (2008). Customized employment: Changing what it means to be qualified in the workforce for transition-aged youth and young adults. Journal of Vocational Rehabilitation, 28, 191-207.

Sabeti, H. (2011). The for-benefit enterprise. Harvard Business Review, 89(11), 98-104.

Schechtman, J. (2010). How to be a social entrepreneur. Source: http://www.newsweek.com/how-be-social-entrepreneur73849

Shipler, D. K. (2008). The working poor: Invisible in America. New York, NY : Vintage Books.

Smith, W. K., Gonin, M., \& Besharov, M. L. (2013). Managing social-business tensions: A review and research agenda for social enterprise. Business Ethics Quarterly, 23(03), 407-442.

The Autism Acceptance Project (2013). Larry Bissonnette. Source: http://www.taaproject.com/?s=LArry

Tomaino, R. (2011). Roses for autism. Exceptional Parent, 41(4), 32-33.

Twenge, J. M. (2014). Generation Me-Revised and Updated: Why Today's Young Americans Are More Confident, Assertive, Entitled-and More Miserable Than Ever Before. New York: Simon and Schuster.

U.S. Department of Labor (2014). Workforce Innovation and Opportunity Act. Source: https://www.doleta.gov/wioa/

U.S. Department of Labor (n.d.). Customized Employment website. Source: https://www.dol.gov/odep/categories/workforce/ CustomizedEmployment/what/index.htm

Verheul, I., Thurik, R., Hessels, J., \& van der Zwan, P. (2010). Factors influencing the entrepreneurial engagement of opportunity and necessity entrepreneurs. EIM Research Reports, 201011, 1-24.

Wagner, E. T. (2013). Five reasons 8 out of 10 businesses fail. Forbes http://www.forbes.com/sites/ericwagner/2013/09/12/ five-reasons-8-out-of-10-businesses-fail/\#6241d4de5e3c

Wehman, P. H., Schall, C. M., McDonough, J., Kregel, J., Brooke, V., Molinelli, A., ...\& Thiss, W. (2014). Competitive employment for youth with autism spectrum disorders: Early results from a randomized clinical trial. Journal of Autism and Developmental Disorders, 44, 487-500.

Wehman, P., Brooke, V., Brooke, A. M., Ham, W., Schall, C., McDonough, J., Lau, S., Seward, H., \& Avellone, L. (2016). Employment for adults with autism spectrum disorders: A retrospective review of a customized employment approach. Research in Developmental Disabilities, 53, 61-72.

Williams, C. C. (2007). Entrepreneurs operating in the informal economy: necessity or opportunity driven? Journal of Small Business \& Entrepreneurship, 20, 309-319.

Williams, C. C. (2009). The motives of off-the-books entrepreneurs: Necessity-or opportunity-driven? International Entrepreneurship and Management Journal, 5, 203-217. 